József Zsolt Kersák ${ }^{1}$ [1 - Ádám István Kiss² [0

\title{
Covid-19 Challenges of the German Federal Agency for Technical Relief (THW) in Germany
}

\section{A Német Szövetségi Müszaki Segítségnyújtás Szervezet (THW) Covid-19-kihívásai Németországban}

The SARS-COV-2 coronavirus presented a new challenge to the world and to defence organisations. In the paper, the authors analyse the composition, task and skills of the so-called Technisches Hilfswerk in Germany. In addition, they describe the applicability of its technical capabilities in the first and second waves of the coronavirus epidemic.

Keywords: THW, Technisches Hilfwerk, logistics, coronavirus, Covid-19

A SARS-CoV-2 koronavírus újfajta kihívások elé állitotta a világ országait és a védekezésben részt vevő szervezeteket. A szerzők a cikkben elemzik a német Technisches Hilfswerk összetételét, feladatrendszerét és képességeit, bemutatják müszaki képességeinek alkalmazhatósági körét a koronavírus-járvány elleni védekezés első és második hullámában.

Kulcsszavak: THW, Technisches Hilfswerk, logisztika, koronavírus, Covid-19

Somogy County Disaster Management Directorate, Siófok Professional Fire Department, e-mail: Jozsef.Kersak@ gmail.com

2 Disaster Management Directorate of the Capital, e-mail: kiss.adam92@gmail.com 


\section{Introduction}

The World Health Organization was informed on 31 December 2019 that cases of pneumonia of unknown etiology was found in Hubei Province in the metropolis of Wuhan. On 7 January 2020, the Chinese authorities identified a new coronavirus (SARS-CoV-2) as a pathogenic virus from which Covid-19 is derived. The wholesale market for fish and seafood in Wuhan was the original site of the infection, whereafter the virus could be diagnosed first in the neighbouring countries and then within a few weeks almost worldwide. The first case of the new coronavirus (SARS-CoV-2) was registered in Germany on 28 January 2020 in Bavaria. In spring, life actually stopped in Germany, because the fight against the coronavirus required radical measures. The Federal Agency for Technical Relief (THW) has played an important role in the fight against the virus as an organisation with technical capabilities. All eight territorial organisations were involved in the complex tasks that arose during the pandemic. The tasks were complex: they built the necessary hospitals, distributed protective equipment, created sampling points, undertook logistics tasks and created crisis teams.

Raphael Scheibler and Michael Kretz have written the following about the tasks of the THW in a scientific paper: 'Logistics was one of the focuses for the first four months after the outbreak in Germany. Many states, counties and municipalities have faced the challenge of obtaining a lot of protective equipment, which must be forwarded as soon as possible to the hospitals, offices and nursing homes. ${ }^{13}$ THW has built and operated logistics bases for the delivery and storage of the protective equipment. Volunteers of the organisation received thousands of equipment, they stored it, and then prepared it for the delivery. In order to mitigate the effects of the pandemic, reduce its spread and maintain the function of the country, the German Federal Agency for Technical Relief still performs important tasks. Their involvement and volunteer work are exemplary in the mechanism of defence.

\section{Introduction of the German Federal Agency for Technical Relief (THW)}

The structure of the Technisches Hilfswerk (Technical Relief) is unique in the world. As a Federal Institution, it works under the competence and supervision of the federal minister of the interior, only a little more than 1 per cent of its members work full time, and nearly 99 per cent of the employees are volunteers. Nationwide, more than 80,000 volunteers work in their spare time in 668 local organisations in order to help those in need.

\footnotetext{
Raphael Scheibler and Michael Kretz, 'THW-Einsätze in der Corona-Krise. Neue Infrastruktur und logistische Hilfe' [THW's operation in the Corona crisis. New infrastructure and logistical assistance]. Crisis Prevention, Fachportal für Gefahrenabwehr, Innere Sicherheit und Katastrophenhilfe, 09 November 2020.
} 
Full-time employees and volunteers within the organization

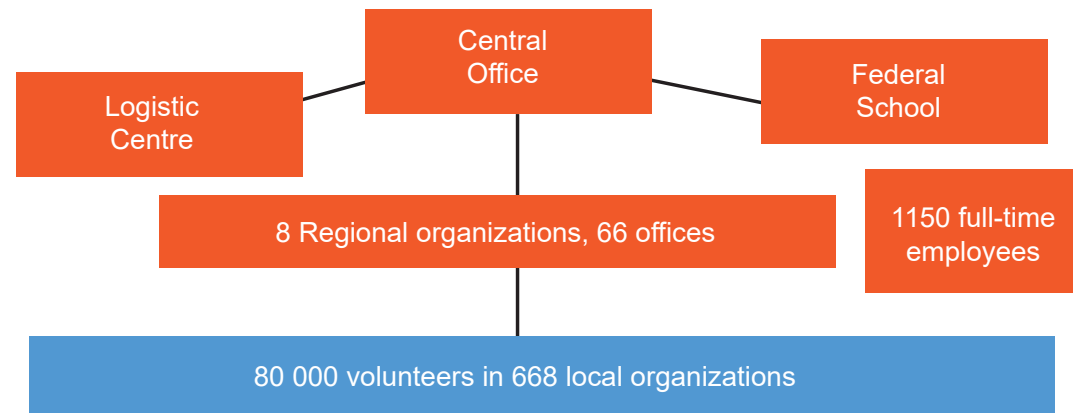

Figure 1. The structure of the Technical Relief

Source: Created and translated by József Zsolt Kersák based on a lecture held at the Bonn Centre on 03. 07. 2017.

Figure 1 shows that from an organisational point of view, the structure of the Technical Relief is unique in the world. They provide assistance under the Civil Protection Act on Disaster Management abroad on behalf of the federal government in the fight against disasters, emergencies and major accidents at the request of the authorities, and in public tasks taken over by agreement. ${ }^{4}$ The protection of human life falls within the legislative competence of the association under the German Basic Law (Article 73), so it is a federal matter. On the other hand, in peacetime and with respect to public security (Article 70), it delegates the system of civil protection tasks to the provincial jurisdiction. ${ }^{5}$ According to the Act on Technical Relief, it is responsible for technical assistance in the field of civil protection as a primary, main task. The concept of civil protection derives from Section 1 of the former Act on Civil Protection. So civil protection is the protection of human life, their residence, work, vital services and facilities. It also included the protection of the cultural heritage threatened by the effects of war and the elimination and mitigation of its consequences. In conclusion, if technical assistance is needed in the field of civil protection, the responsible organisation is the THW.

Section 3 of the Act on Technical Relief provides for the possibility of mutual assistance. ${ }^{6} \mathrm{It}$ means that the authorities responsible for fighting against the dangers are not obliged to use its help, but the organisation is obliged to provide assistance if it is requested. It is important to state that it is able to provide technical assistance in accordance with the general provisions on mutual assistance.

4 Gesetz über den Zivilschutz und die Katastrophenhilfe des Bundes (Zivilschutz- und Katastrophenhilfegesetz-ZSKG) [Law on civil protection and federal disaster aid], 2009.

5 Grundgesetz für die Bundesrepublik Deutschland [Basic Law for the Federal Republic of Germany].

6 Gesetz über das Technische Hilfswerk [Act on the Federal Agency for Technical Relief]. 


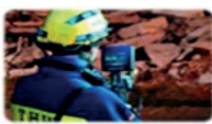

Search

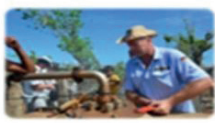

Repair

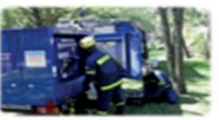

Electricity supply

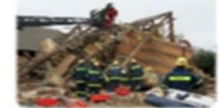

Saving material goods

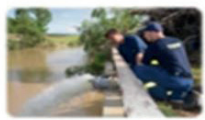

Pumping

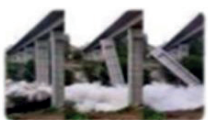

Blasting

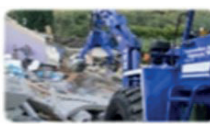

Recovery

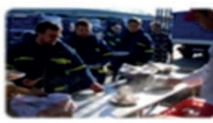

Service

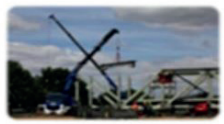

Bridge construction

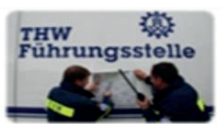

Coordination

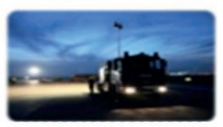

Lighting

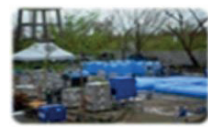

Water cleaning

Figure 2. Type of THW interventions

Source: Created and translated by József Zsolt Kersák based on a lecture held at the Bonn Centre on 03. 07. 2017.

The organisation can be applied in six different areas.

- Technical assistance in the field of infrastructure: electricity supply, drinking water supply, hygiene, bridge construction.

- In the field of technical safety: research, rescue, rescue of objects, blasting, rescue from water, flood and flood protection, prevention, lighting of workspace.

- Management/communication in the field of logistics: creating and operating the control points, management support, setting up temporary telecommunication systems, setting up and operating logistical bases, organising and maintaining emergency care, maintenance and supply of equipment.

- Technical assistance in the field of environmental protection: cleaning after oil pollution, water tests.

- Population service: provision of electricity and drinking water supply, hygiene.

- Further technical assistance: technical assistance on transport routes, rescue from high buildings, diving, road construction, maintenance of civil protection facilities (emergency wells, shelters), construction and equipping of temporary shelters and collection points, construction of infrastructure. ${ }^{7}$ 


\section{Tasks of the THW during the Covid-19 crisis}

'We can only judge in review what was correct if a self-critical evaluation of the experience is made.'

Albrecht Broemme

Leader of the THW (2006-2019)

The first 'wave'

In the fight against coronavirus, THW has provided important health assistance throughout Germany with its extensive interventions to slow the spread of the virus. During the corona crisis to ensure the medical supplies and protective equipment, the federal government purchased the necessary protective equipment and disinfectants centrally. The Federal Ministry of the Interior (BMI) has commissioned the THW to organise and distribute the centrally procured infection control components. This was done in accordance with the resolution of the various departments of the federal administration, the Federal Government Crisis Group. To make this happen, THW has set up a central logistics coordination unit in addition to an active crisis team. This is assigned to the head of the intervention department in the THW management and it is supported by the staff of the logistics department.

The second 'wave'

The second 'wave' has also reached Germany, the protection measures were taking place in the following way: Germany gets vaccines in a centralised way at federal level. The purchasing task is part of the first phase, which is described as follows. For example in Berlin, nearly one million vaccines have to be procured, stored and delivered to vaccination points. After the injection of the vaccines, any remaining unused stock should be exempted and destroyed. Vaccination centres are plan planned to accomplish this phase. Hundreds of such centres are being built across Germany, 6 of them are planned to be set up in Berlin. Building these vaccination centres is a technical challenge for architects and designers. The task must not only be carried out quickly, but the safety distance and hygiene standards must also be observed in accordance with epidemiological standards. The operation will be another major challenge. Sufficient staff must also be provided to operate these centres. In the third phase, the solution is to get the right groups of people in time to and from the vaccination centres. 


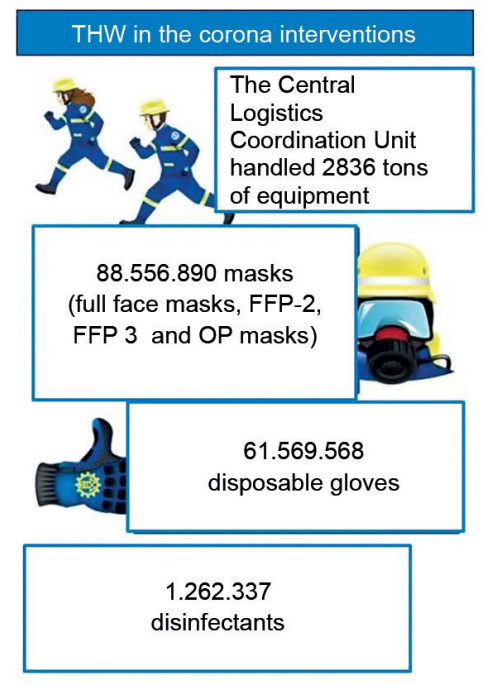

Figure 3. THW in the corona interventions

Source: THW's official Facebook page, translated by the authors.

THW counts around 200 security staff for the operation of each vaccination centre in Berlin. From morning to evening, they take part in vaccination tasks - in addition to health professionals - twelve hours a day, every day of the week. At this point, the disaster management will have the special task of involving as many voluntary people as possible in full time and providing the necessary staff for several weeks. THW is not only applicable for helping to set up vaccination centres to fight against the coronavirus epidemic. THW provides logistical support nationwide for the purchasing, storage and transportation of protective equipment or disinfectants. Central logistics coordination serves as a centre for materials procured by the federal government.

\section{Summary}

It is important to mention that in a pandemic situation health organisations have the most important tasks. These organisations have the competencies to reduce or prevent the spread of the virus. The Federal Agency for Technical Relief (THW) has technical competencies in the field of civil protection. The technical capability of the organisation was applied in a professional manner against the Covid-19 pandemic.

\section{References}

Gesetz über den Zivilschutz und die Katastrophenhilfe des Bundes (Zivilschutz- und Katastrophenhilfegesetz - ZSKG) [Law on civil protection and federal disaster aid], 2009. Online: www.bbk. bund.de/SharedDocs/Downloads/BBK/DE/FIS/Zivilschutz-Katastrophenhilfegesetz.pdf?_blob=publicationFile 
Grundgesetz für die Bundesrepublik Deutschland [Basic Law for the Federal Republic of Germany]. Online: www.gesetze-im-internet.de/gg/BJNR000010949.html

Gesetz über das Technische Hilfswerk [Act on the Federal Agency for Technical Relief]. Online: www. thw.de/DE/THW/Bundesanstalt/Auftrag/auftrag_node.html?noMobile=1

Gesetz über das Technische Hilfswerk [Act on the Federal Agency for Technical Relief operational possibilities]. Online: www.thw.de/DE/THW/Bundesanstalt/Aufgaben/Einsatzoptionen/einsatzoptionen_node.html

Scheibler, Raphael and Michael Kretz, 'THW-Einsätze in der Corona-Krise. Neue Infrastruktur und logistische Hilfe' [THW's operation in the corona crisis. New infrastructure and logistical assistance]. Crisis Prevention, Fachportal für Gefahrenabwehr, Innere Sicherheit und Katastrophenhilfe, 09 November 2020. Online: https://crisis-prevention.de/katastrophenschutz/thw-einsaetze-inder-corona-krise.html 